\title{
Tradición y cultura crítica. A propósito del Toro de la Vega
}

Keywords: maltrato animal; Toro de la Vega; cultura; tradición

Cuando se enarbola la tradición para justificar actos que podrían ser prohibidos o castigados, si no estuvieran protegidos por el calificativo de tradicionales, algo no funciona.

Cuando la tradición se escribe con mayúscula, para blindarse contra el sano y necesario ejercicio de la crítica, algo no funciona.

Cuando con el apelativo de tradición, se legitima el ejercicio de la violencia contra cualquier ser vivo, algo no funciona.

De entre los diversos significados que el término tradición tiene hoy en día, no debe olvidarse que tradición es siempre transmisión, o simple entrega de algo sin ningún tipo de ceremonia o de ritual. Esto es lo que el término traditio significa, ni más ni menos. Y este es el núcleo semántico que conservan las distintas acepciones derivadas del término tradición. Desde el punto de vista cultural, se entiende por tradición un hábito social, un conjunto de actos, una celebración incluso, que se convierte en un uso aceptado por una sociedad. A dicha acepción de tradición, es a la que hacemos aquí referencia

La tradición no conlleva, por sí misma la perpetuidad. Es cierto, que tampoco - como pretendía cierto alcalde de un pueblo-, puede "inaugurarse una tradición". Sí es connatural a la tradición, que se acepte por la sociedad y que forme parte del acervo de la cultura de un pueblo, pero ello no implica que lo que ha sido una tradición viva, pueda dejar de serlo, porque los hábitos sociales van cambiando y lo que en un determinado momento era aceptable, puede convertirse en algo inaceptable e inadaptado a la sociedad que lo contempla. Mientras que la ley ofrece un límite a las conductas, la tradición implica un trasfondo positivo, tiene un sentido dinámico, un principio de continuidad fecunda, que se reafirma, modifica y completa por su misma congruencia interna, sin inmovilismo, lo que no siempre se incluye en la posibilidad de que un uso tradicional desaparezca. Hace falta poner ejemplos?.

La tradición no debería de ser inmune a la crítica, sobre todo cuando los cambios sociales, revelan que un uso o un acto considerado como tradicional, deja de tener una aceptación indiscutida y, sobre todo, cuando la sensibilidad social rechaza tal tradición. En los momentos, en que una sociedad se alza en contra de la perpetuidad y la anuencia sin crítica de un uso o una costumbre tradicional, dicha sociedad debe exigir que tal tradición desaparezca, mucho más si en tal tradición coexiste el uso de la violencia. Tampoco puede la tradición ser ajena al Derecho y convertirse en un reducto intocable, que se superpone y resiste al ejercicio de la crítica y de la regulación normativa.

Propongo estas reflexiones como antecedente de lo que considero una polémica actual, mal planteada. El Toro de la Vega está, desde hace unos años, en el foco de la protesta de quienes consideran que es un espectáculo indigno, de violencia legitimada contra un animal, que resiste difícilmente, poco más de media hora, a los embates de los caballistas o de los lanceros de a pie, que lo derriban de un lanzazo y lo rematan con un descabello. Es una celebración tradicional de Tordesillas y los defensores de la misma se escudan en que el rito, con ocasión de una fiesta religiosa en honor de la Virgen de la Peña, se remonta a la Edad Media y han uncido su identidad, de forma acrítica, a la muerte cruel de un animal a campo abierto. 
Pues ahí está el error, en resistirse a lo que es un sano ejercicio de la libertad de expresión (aunque deberían de suprimirse las pedradas y los insultos), por parte de la sociedad que ha cambiado su visión acerca de los animales: se ha sensibilizado al sufrimiento de los que el Derecho ya considera "seres sintientes" y tal dato, contemplado desde una perspectiva global, es innegable.

La Unión Europea viene celebrando, precisamente en el 2014, 40 años de Bienestar Animal. Es decir, 40 años de legislación para la protección de los animales en sus intereses básicos, uno de los cuales es no morir para diversión de nadie. Los espectáculos cruentos con animales están obsoletos y si la sociedad ya lo ha percibido y lo rechaza cada día más, es ahora el turno del Derecho, aplicado a los casos concretos como es la celebración del Toro de la Vega, que no puede seguir amparándose en que es una tradición para quedar al margen de la regulación jurídica, que, sin excepciones, debe suprimir y castigar todo acto de violencia ejercida contra los animales. No cabe aquí invocar a Max Weber, para blindar los espectáculos sangrientos con animales como expresión de violencia legítima, más bien al contrario, no puede seguir usándose el recurso de la polémica política, que sea utilizable en cualquier caso de contradicción con la legalidad actual, para seguir manteniendo una tradición que ya debería, hace tiempo, haber desaparecido. 